\title{
FIRST RECORD OF Daphnia lumholtzi (SARS, 1885), EXOTIC CLADOCERAN, IN SÃO PAULO STATE (BRAZIL)
}

\author{
ZANATA, L. H., ${ }^{1}$ ESPÍNDOLA, E. L. G., ${ }^{1}$ ROCHA, O. ${ }^{2}$ and PEREIRA, R. H. G. ${ }^{3}$ \\ ${ }^{1}$ Núcleo de Estudos de Ecossistemas Aquáticos, Centro de Recursos Hídricos e Ecologia Aplicada, SHS, EESC, \\ USP, Av. Trabalhador Sancarlense, 400, C.P. 292, CEP 13560-970, São Carlos, SP, Brazil \\ ${ }^{2}$ Universidade Federal de São Carlos, Departamento de Ecologia e Biologia Evolutiva, \\ C.P. 676, CEP 13565-905, São Carlos, SP, Brazil \\ ${ }^{3}$ Centro Universitário de Aquidauana, Universidade Federal de \\ Mato Grosso do Sul, Aquidauana, MS, CEP 79200-000, Brazil \\ Correspondence to: Evaldo L. G. Espíndola, Núcleo de Estudos de Ecossistemas Aquáticos, \\ Centro de Recursos Hídricos e Ecologia Aplicada, SHS, EESC, USP, Av. Trabalhador Sancarlense, 400, \\ C.P. 292, CEP 13560-970, São Carlos, SP, Brazil, e-mail: elgaeta@sc.usp.br \\ Received May 17, 2002 - Accepted August 29, 2002 - Distributed November 30, 2003
}

(With 2 figures)

Daphnia lumholtzi was recently found at Três Irmãos Reservoir, São Paulo State, Brazil (21 ${ }^{\circ} 45^{\prime}$ S e $49^{\circ} 47^{\prime} \mathrm{W}$ ) (Fig. 1).

Daphnia lumholtzi is a species of the family Daphnidae, Cladocera, with natural geographic distribution restricted to Australia, southwestern Asia, and Africa. It has invaded the United States and rapidly dispersed during the last decade (Havel \& Hebert, 1993) after its first appearance in 1989 (Havel et al., 2000).

The occurrence of this species in the New World was considered peculiar. Some authors have suggested that intercontinental dispersion of cladocerans is rare, although the production of resting eggs and the parthenogenetic reproduction mode have been facilitating dispersion (Dodson \& Frey, 1991). According to Havel \& Hebert (1993), another dispersion agent could be the introduction into reservoirs of fishes for angling purposes. Once the species reaches the new continent, its dispersal could be by means of boats used for recreational activities.

Resistance to predation might be a determinant factor in the successful invasion of this species because the carapace spine and helmet of $D$. lumholtzi protect against invertebrate predation (Kolar \& Wahl, 1998), although this is still a matter of speculation because the real protective potential of such structures is not well known (Dzialowski et al., 2000). Many invaders are successful because, besides resistance to predation (Crawley, 1986), either native competitors are ineffective or other species do not take advantage of existing opportunities.
The morphology of $D$. lumholtzi, as described by Sars (1885), clearly shows great differences when compared to the three species of Daphnia occurring in Brazilian water bodies: $D$. laevis, D. gessneri, and D. ambigua (Matsumura-Tundisi, 1984). The distinctive features are the presence of lateral fornices, ventral margin of carapace with 12 strong spines, and postabdomen with characteristic processes (Korínek, 1999; Korínek, 2002; Smirnov \& Timms, 1983). According to Sars (1885), adult females can reach $1.3 \mathrm{~mm}$ mean length and adult males $1.0 \mathrm{~mm}$, with variations depending on environmental conditions. The species diagnosis includes: head usually with a narrow, anterior projecting crest, but may be absent in dense populations; antennular mounds very well developed and situated close to the rostrum; tail varying from one-half to slightly more than carapace length.

Figure 2 shows morphological characteristics of $D$. lumholtzi found in Três Irmãos Reservoir. Male characteristics are: head usually unhelmeted, with a small spike-shaped crest occasionally present; dorsal postabdominal margin strongly sinuate; tail about two-thirds of carapace length.

$D$. lumholtzi has not been previously reported in the Neotropical region. In Brazil, in October 2000 it was found in both transition and lacustrine regions in Três Irmãos, a large reservoir (81.700 ha) located in the Tietê River, in samples concentrated in a plankton net ( $30 \mu \mathrm{m}$ mesh size) collected by pumping water of the entire water column. In the transition zone the population density was 55 ind. $\mathrm{m}^{-3}$, whereas in the lacustrine region near the dam, it occurred at densities of 100 ind. $\mathrm{m}^{-3}$. 
718

ZANATA, L. H. et al.
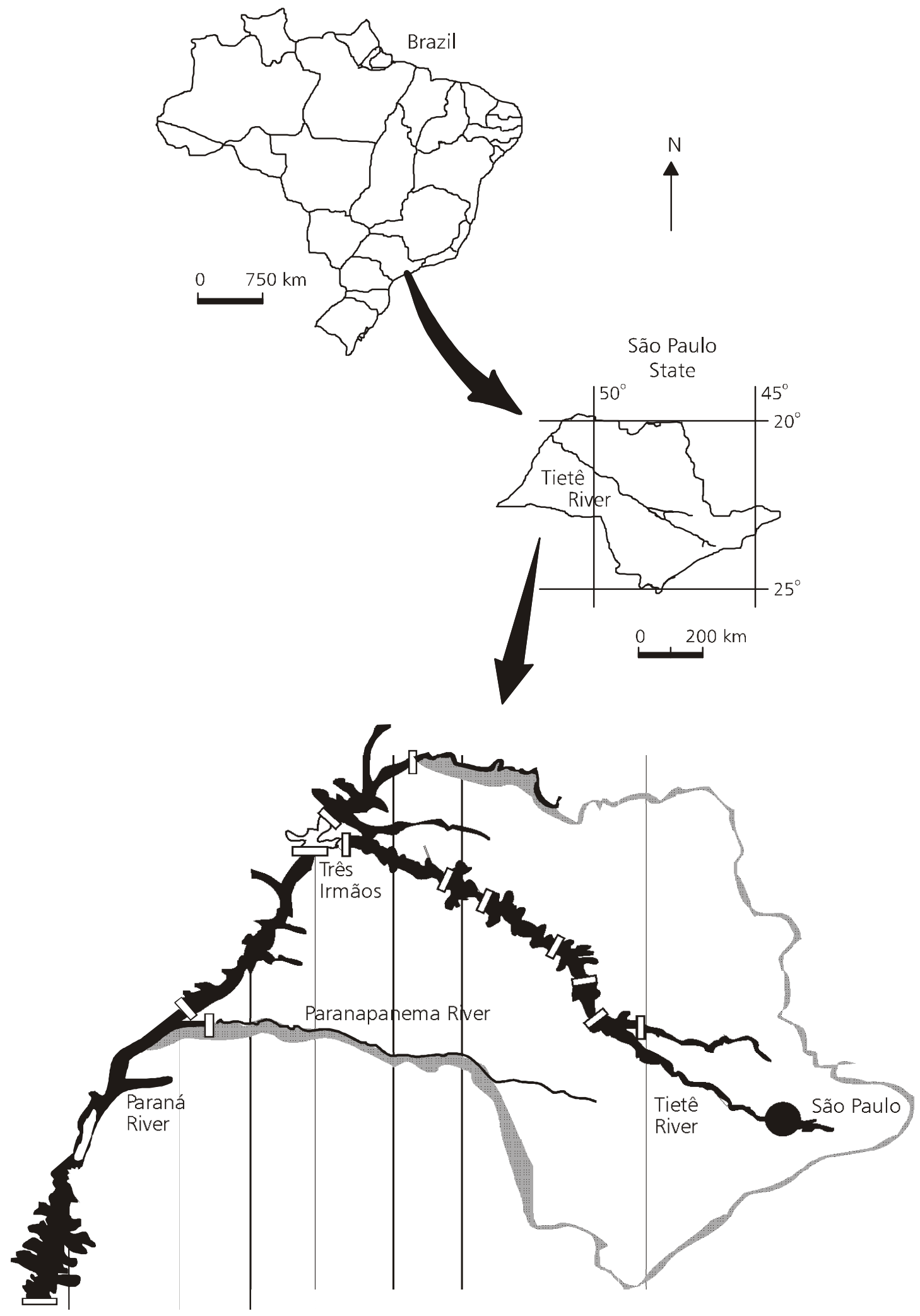

Fig. 1 - The location of Três Irmãos Reservoir in São Paulo State, Brazil.

Braz. J. Biol., 63(4): 717-720, 2003 

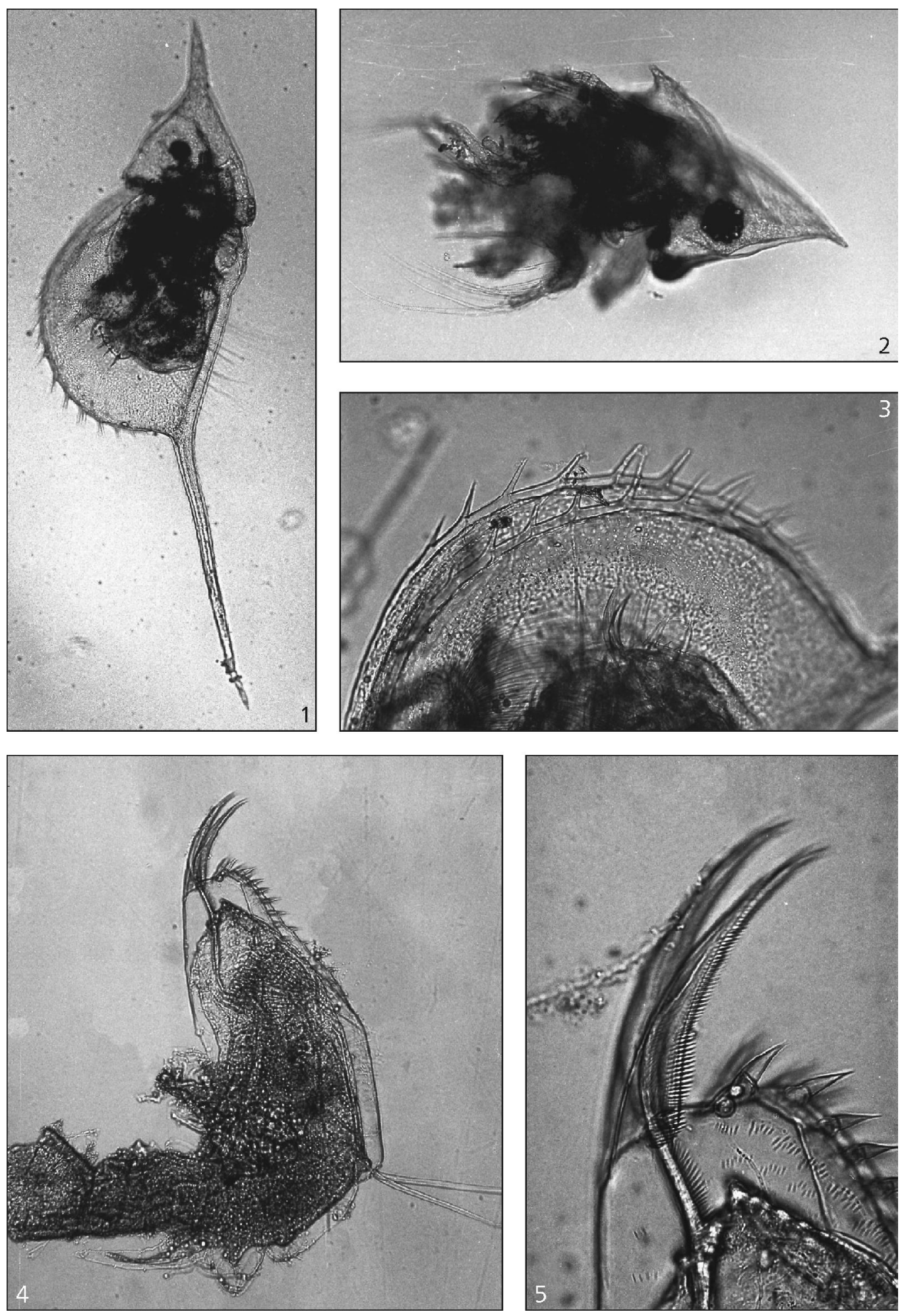

Fig. 2 - Daphnia lumholtzi collected in Três Irmãos Reservoir, São Paulo State, Brazil. 1. General view of female (x 320 ); 2. fornice (x 200); 3. spines in the ventral carapace (x 640); 4. postabdomen (x 400); and 5. claw (x 640). 
The observed densities suggest that the species population is in the colonization phase in Três Irmãos Reservoir. In the Great Lakes in North America, the average number in the initial colonization phase was 30 ind. $\mathrm{m}^{-3}$ (Muzinic, 2000). According to Dzialowski et al. (2000), D. lumholtzi has a wide ecological tolerance, but the reservoirs where invasion has been successful tend to be large, deep, with high Secchi Disk transparency and low levels of phosphorus, nitrogen, and chlorophyll $a$. Maximum concentrations of total phosphorus and total organic nitrogen in Três Irmãos Reservoir were $75.74 \mu$ g. $\mathrm{L}^{-1}$ and $0.43 \mathrm{mg} . \mathrm{L}^{-1}$, respectively. The euphotic region has a $14.1 \mathrm{~m}$ extension and a mean chlorophyll $a$ concentration of $5 \mu \mathrm{g}$. $\mathrm{L}^{-1}$. It therefore appears that the limnological characteristics of Três Irmãos Reservoir are favorable to the successful colonization of $D$. lumholtzi. Temperature is also considered an important factor in this species' survival. Work \& Gophen (1999) point out that D. lumholtzi is originally a subtropical species reaching peak abundance at high temperatures $\left(27\right.$ to $\left.30^{\circ} \mathrm{C}\right)$ in many freshwater systems in the United States. Water temperature at Três Irmãos reservoir in October 2000 varied between 21.6 to $26.2^{\circ} \mathrm{C}$, close to the range considered ideal by those authors.

It is a matter of great concern that, in Brazilian freshwaters, the establishment of an exotic zooplankton species such as D. lumholtzi might drive the extinction of other native daphnids. Efforts must be directed to closely following the interaction between the native and the exotic species.

Aknowledgments - The authors are grateful to CNPq for the $\mathrm{PhD}$ grant to the first author; to FAPESP (BIOTA Program) and to the Ministry of Environment and National Research Council (PROBIO Program - MMA/CNPq/BIRD/GEF) for financial support of the project "Monitoring and development of technologies for managing freshwater exotic species". They also thank Katia Sendra Tavares, Maria José Dellamano de Oliveira, and Magno Botelho Castelo Branco for valuable help with photographs and image processing.

\section{REFERENCES}

CRAWLEY, M. J., 1986, The population biology of invaders. Phil. Trans. R. Soc. Lond. B., 314: 711-731.

DODSON, S. I. \& FREY, D. G., 1991, Cladocera and other Branchiopoda. In: J. H. Thorpe \& A. P. Covich (eds.), Ecology and classification of North American freshwater invertebrates. Academic Press, San Diego, Calif., pp. 723786.

DZIALOWSKI, A. R., O'BRIEN, W. J. \& SWAFFAR, S. M., 2000, Range expansion and potential dispersal mechanisms of the exotic cladoceran Daphnia lumholtzi. J. Plankton Res., 22(12): 2205-2223.

HAVEL, J. E., COLBOURNE, J. K. \& HEBERT, P. D. N., 2000, Reconstructing the history of intercontinental dispersal in Daphnia lumholtzi by use of genetic markers. Limnol. Oceanogr., 45(6): 1414-1419.

HAVEL, J. E. \& HEBERT, P. D. N., 1993, Daphnia lumholtzi in North America: another exotic zooplankter. Limnol. Oceanogr., 38(8): 1823-1827.

KOLAR, C. S. \& WAHL, D. W., 1998, Daphnid morphology deters fish predators. Oecologia, 116: 556-564.

KORÍNEK, V., 1999, A guide to limnetic species of Cladocera of African inland waters (Crustacea, Branchiopoda). Occasional Publication n. 1, Geneva, International Association of Theoretical and Applied Limnology, BLT, 57p.

KORÍNEK, V., 2002, Cladocera. In: C. H. Fernando (ed.), A guide to tropical freshwater zooplankton. Leiden, The Netherlands, Backhuys Publishers, pp. 69-122.

MATSUMURA-TUNDISI, T., 1984, Occurrence of species of the genus Daphnia in Brazil. Hydrobiologia, 112: 161-165.

MUZINIC, C. J., 2000, First record of Daphnia lumholtzi Sars in the Great Lakes. J. Great Lakes Res., 26(3): 352-354.

SARS, G. O., 1885, On some Australian Cladocera raised from dried mud. Forhandlinger $i$ Videnskabs-Selskabet $i$ Christiania, pp. 1-46.

SMIRNOV, N. N. \& TIMMS, B. V., 1983, A revision of the Australian Cladocera (Crustacea). Rec. Austral. Mus., Suppl. 1., $132 \mathrm{p}$.

WORK, K. A. \& GOPHEN, M., 1999, Factors which affect the abundance of an invasive cladoceran, Daphnia lumholtzi, in U.S. reservoirs. Freshwater Biol., 42(1): 1-10. 